\title{
Evaluating the potential of indigenous Rhizobacteria as biofertilizer and biopesticide against Rhizoctonia solani
}

\author{
MAIMUNA NONTJI ${ }^{1, \bullet}$, AMRAN MUIS ${ }^{2}$, NURMI NONCI ${ }^{3}$, NURJANNAH NONCI ${ }^{4}$, \\ FARIZAH DHAIVINA AMRAN ${ }^{5}$ \\ ${ }^{1}$ Department of Agrotechnology, Faculty of Agriculture, Universitas Muslim Indonesia. Jl. Urip Sumoharjo Km. 5, Makassar 90231, South Sulawesi, \\ Indonesia. Tel.: +62-411-440412, Fax.: +62-411-455695, ”email: mey.amin68@ gmail.com \\ ${ }^{2}$ Indonesian Cereals Research Institute. J1. Dr. Ratulangi No. 274, Maros 90512, South Sulawesi, Indonesia \\ ${ }^{3}$ Departement of Sociology, Faculty of Social, Universitas Bosowa. Jl. Urip Sumoharjo Km 5, Makassar 90231, South Sulawesi, Indonesia \\ ${ }^{4}$ Department of Social, STISIP Muhammadiyah Rappang. J1. Angkatan 45, Lt. Salo, Rappang 91651, South Sulawesi, Indonesia \\ ${ }^{4}$ Department of Agribusiness, Faculty of Agriculture, Universitas Muslim Indonesia. Jl. Urip Sumoharjo Km. 5, Makassar 90231, South Sulawesi, Indonesia
}

Manuscript received: 21 September 2018. Revision accepted: 17 March 2019.

\begin{abstract}
Nontji M, Muis A, Nonci N, Nonci N, Amran FD. 2019. Evaluating the potential of indigenous Rhizobacteria as biofertilizer and biopesticide against Rhizoctonia solani. Nusantara Bioscience 11: 79-83. Rhizobacteria are living in area of plant roots, some of them are potential as biofertilizers and biopesticides agents. This study aims to evaluate the potential of 10 isolates indigenous rhizobacteria as biofertilizer and biopesticide against banded leaf and sheath blight disease on corn. The potential of biofertilizer was evaluated by ability fixing nitrogen in Burk's $\mathrm{N}$ free medium, dissolving phosphate and producing Indole Acetic Acid (IAA) hormone with spectrophotometry method. The potential of biopesticide was evaluated by synergistic of analysis with double culture method. The result of study showed that the best indigenous rhizobacteria was isolated code 10 . It has potential as a biofertilizer agent $(0.22 \%$ for fixing nitrogen, $18.875 \mathrm{ppm}$ for dissolving phosphate and producing IAA hormone $1.524 \mathrm{ppm}$ ). It is also having potential as biopesticide agent against Rhizoctonia solani with relative inhibition level (RIL) of 31.3\%. Isolate code 10 and code 6 are able to live in synergy so that it can be recommended as biofertilizer and biopesticide agent to form the consortium as a biological fertilizer.
\end{abstract}

Keywords: Biofertilizer, biopesticide, disease, pathogen, rhizobacteria

\section{INTRODUCTION}

Utilization of several rhizobacteria as a biological agent is very appropriate because it is more environmentally friendly. Biological control using microorganisms associated with rhizosphere and organic matter is an efficient and environmentally friendly approach. In addition, some rhizobacteria potentially provide, mobilized and facilitate the absorption of various nutrients in the soil, because of its ability to bind nitrogen and produce hormone.

Indigenous rhizobacteria isolated from Gowa and Takalar districts have the ability to reduce methane gas by up to $88 \%$ (Nonci et al. 2016). It has also been found that several rhizobacteria have nitrogenase activity. Bao et al. (2014) reported that the result from the metaproteomic analysis suggest that $\mathrm{N}_{2}$ fixation is mainly performed by type II methanotrophs, including Methylosinus sp., which inhabit the vascular bundles and epidermal cells of rice roots. Khadem et al. (2010) reported on nitrogen fixation within the phylum Verrucomicrobia that ammonium concentrations up to $94 \mathrm{mM}$ did not inhibit the nitrogenase activity; therefore it is potential as biofertilizer agents.

Rhizosphere bacteria can play a role as biofertilizer and bioprotectant (Ashrafuzzamanet et al. 2009). Based on these facts, it is possible that indigenous rhizobacteria besides functioning as bioremediation agents, also have the biopesticide agents against Rhizoctonia solani, causing banded leaf and sheath blight. This disease could result in production losses of up to $100 \%$. Zhang et al. (2009) reported that Bacillus as biocontrol agents had been used to control soil-borne phytopathogens that affect many host plants (Zhang et al. 2009). Isolation of indigenous rhizobacteria originating from Gowa and Takalar districts has been carried out and succeeded in collecting ten isolates that have potential as bioremediation agents. The potential of these bacteria needs to be further analyzed. The objective of this research is to obtain excellent indigenous rhizobacteria as biofertilizer for increasing maize productivity and biopesticide agents against banded leaf and sheath blight.

\section{MATERIALS AND METHODS.}

This research was conducted from April to June at the Plant Pathology Laboratory and Soil Laboratory of Cereals Research Institute, Maros District, South Sulawesi, Indonesia. The pathogenic fungi used were $R$. solani, collections of Plant Pathology Laboratory, and the test bacteria used were 10 indigenous rhizobacteria collection of research preview (Nonci et al. 2016) from Gowa and Takalar Districts, South Sulawesi, Indonesia. 


\section{Analysis of indigenous Rhizobacteria as biofertilizer Nitrogen fixation}

Potential of indigenous rhizobacteria in binding Nitrogen was tested by culturing isolates on liquid medium of Burk's N-free with three replications. The $\mathrm{pH}$ of the medium is adjusted to $\mathrm{pH} 7.3$ before sterilization. Then placed on shaker for 24 hours at $28^{\circ} \mathrm{C}$ (Stella et al. 2010).

Isolates capable of growing on Burk's $\mathrm{N}$-free medium are indicated as isolates capable to fixing nitrogen. Nitrogen content was calculated by using the formula as follows:

\section{Nitrogen content $(\%)=(\mathrm{Vc}-\mathrm{Vb}) \times \mathrm{N}$ x bst $\mathrm{N}$ x $100 \mathrm{mg}$ sample-1}

\section{Where:}

$\mathrm{Vc}, \mathrm{b}=$ volume of sample titration $(\mathrm{ml})$

$\mathrm{N}=$ normality of $\mathrm{H}_{2} \mathrm{SO} 4$ standard solution

bst $\mathrm{N}=$ Equivalent weight 14

\section{Phosphate dissolution}

The ability of bacteria to dissolve phosphate was done by quantitative analysis on liquid Phikovkaya medium with three replications. Thirty $\mathrm{ml}$ isolate cultures were cultured on medium and incubated above $100 \mathrm{rpm}$ for 7 days at room temperature. After incubation completed, culture medium was then centrifuged for 15 minutes. Supernatant was added with $0.5 \mathrm{ml}$ of concentrated $\mathrm{P}$ reagent $(12 \mathrm{~g}$ of Ammonium molybdate, $0.2777 \mathrm{~g}$ of Potassium antimoltartrate). Shaker for a few minutes and then left for 30 minutes. The $\mathrm{pH}$ of the solution was measured, before measuring the absorbance of the phosphate dissolution rate. The absorbance of the solution was measured at $693 \mathrm{~nm}$, the color change to blue indicates a positive sign to phosphate dissolution test.

Standard phosphate curve (tittrisol) was made of dilution concentrations ranging from 0 to $2.5 \mathrm{mgl}^{-1}$, with linear regression equation of $\mathrm{Y}=0.191 \mathrm{X}+0.048$, with $\mathrm{R}^{2}$ value $=0.957$.

\section{Production Indole Acetic Acid (IAA) growth hormones}

IAA was determined by spectrophotometric method at the wavelength of $535 \mathrm{~nm}$ (Guitierrez et al. 2009). The bacterial isolates were cultured on Nutrient Broth liquid medium added with L-Tryptophan $0.1 \mathrm{ppm}$ as a precursor, then incubated at $28^{\circ} \mathrm{C}$ under dark condition for 5 days. After incubation, culture was centrifuged for 10 minutes at $8000 \mathrm{rpm}$. One $\mathrm{ml}$ of supernatant was added with $1 \mathrm{ml}$ Salkowski reagent and incubated for 24 hours at $28^{\circ} \mathrm{C}$ under dark condition.

The color change medium to pink indicates that the isolates have ability to produce IAA. Standard curve IAA was made dilution IAA stock solution with concentrations ranging from 0 to $5.0 \mathrm{mg} \mathrm{l}^{-1}$, with the regression equation of $\mathrm{Y}=0.064 \mathrm{X}+0.09$, where $\mathrm{R} 2=0.995$.

\section{Analysis of biopesticide}

The antagonistic test was performed separately using a double culture method with direct opposition (Figure 1), between isolates R.solani and indigenous rhizobacteria on Potato Dextrose medium. The tested pathogen was taken from a seven-day culture using $3 \mathrm{~mm}$ diameter cork borer, while the test bacteria were taken from a week-old culture. Each pair is repeated five times and then incubated at room temperature. Parameters observed were clear zone diameter and relative inhibitory level (RIL).

The calculation of the resistor level is calculated by using the formula as follows:

$$
\mathrm{RIL}==\frac{d k-d p}{d k} x 100 \%
$$

Where:

RIL = relative inhibitory level

$\mathrm{dk}=$ diameter of $R$. solani colony on control

$\mathrm{dp}=$ diameter of $R$. solani colony at treatment

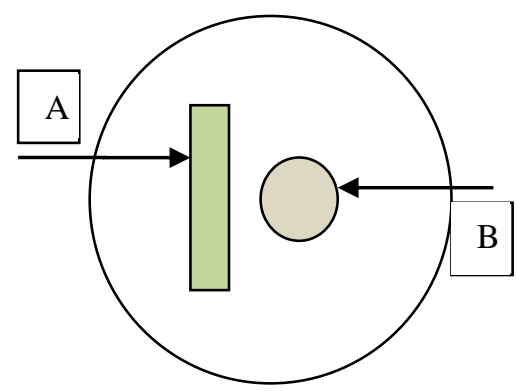

Figure 1. Multiple culture method; A. R.solani, B. Indigenous rhizobacteria

\section{Analysis of synergistic}

Indigenous rhizobacteria that antagonistic against $R$. solani were analyzed using a synergy test to obtain synergistic isolates. The test was performed by a double culture method, between bacteria and other isolates simultaneously both acting as isolate target and isolate test. The isolates target of $2.5 \mathrm{ml}$ were cultured on Nutrient broth liquid medium with a concentration of $10^{8} \mathrm{Cfu} / \mathrm{ml}$, then inoculated on a Nutrient agar solid medium by spreading it evenly on the surface of the medium. The "blank discs" paper $(\mathrm{d}=5 \mathrm{~mm})$ were immersed in the suspension of the bacterial isolate at a concentration of $10^{8}$ $\mathrm{Cfu} / \mathrm{ml}$, then placed on the surface of the inoculated medium with the isolated test. The synergistic analysis matrix between isolate target and isolate test was designed as in Table 1.

Table 1. Matrix of synergistic between isolate target and isolate test

\begin{tabular}{ccccccccccc}
\hline Isolate & \multicolumn{10}{c}{ Isolate test } \\
\cline { 2 - 11 } target & $\mathbf{1}$ & $\mathbf{2}$ & $\mathbf{3}$ & $\mathbf{4}$ & $\mathbf{5}$ & $\mathbf{6}$ & $\mathbf{7}$ & $\mathbf{8}$ & $\mathbf{9}$ & $\mathbf{1 0}$ \\
\hline 1 & $\mathrm{nt}$ & $\mathrm{t}$ & $\mathrm{t}$ & $\mathrm{t}$ & $\mathrm{t}$ & $\mathrm{t}$ & $\mathrm{t}$ & $\mathrm{t}$ & $\mathrm{t}$ & $\mathrm{t}$ \\
2 & $\mathrm{nt}$ & $\mathrm{nt}$ & $\mathrm{t}$ & $\mathrm{t}$ & $\mathrm{t}$ & $\mathrm{t}$ & $\mathrm{t}$ & $\mathrm{t}$ & $\mathrm{t}$ & $\mathrm{t}$ \\
3 & $\mathrm{nt}$ & $\mathrm{nt}$ & $\mathrm{nt}$ & $\mathrm{t}$ & $\mathrm{t}$ & $\mathrm{t}$ & $\mathrm{t}$ & $\mathrm{t}$ & $\mathrm{t}$ & $\mathrm{t}$ \\
4 & $\mathrm{nt}$ & $\mathrm{nt}$ & $\mathrm{nt}$ & $\mathrm{nt}$ & $\mathrm{t}$ & $\mathrm{t}$ & $\mathrm{t}$ & $\mathrm{t}$ & $\mathrm{t}$ & $\mathrm{t}$ \\
5 & $\mathrm{nt}$ & $\mathrm{nt}$ & $\mathrm{nt}$ & $\mathrm{nt}$ & $\mathrm{nt}$ & $\mathrm{t}$ & $\mathrm{t}$ & $\mathrm{t}$ & $\mathrm{t}$ & $\mathrm{t}$ \\
6 & $\mathrm{nt}$ & $\mathrm{nt}$ & $\mathrm{nt}$ & $\mathrm{nt}$ & $\mathrm{nt}$ & $\mathrm{nt}$ & $\mathrm{t}$ & $\mathrm{t}$ & $\mathrm{t}$ & $\mathrm{t}$ \\
7 & $\mathrm{nt}$ & $\mathrm{nt}$ & $\mathrm{nt}$ & $\mathrm{nt}$ & $\mathrm{nt}$ & $\mathrm{nt}$ & $\mathrm{nt}$ & $\mathrm{t}$ & $\mathrm{t}$ & $\mathrm{t}$ \\
8 & $\mathrm{nt}$ & $\mathrm{nt}$ & $\mathrm{nt}$ & $\mathrm{nt}$ & $\mathrm{nt}$ & $\mathrm{nt}$ & $\mathrm{nt}$ & $\mathrm{nt}$ & $\mathrm{t}$ & $\mathrm{t}$ \\
9 & $\mathrm{nt}$ & $\mathrm{nt}$ & $\mathrm{nt}$ & $\mathrm{nt}$ & $\mathrm{nt}$ & $\mathrm{nt}$ & $\mathrm{nt}$ & $\mathrm{nt}$ & $\mathrm{nt}$ & $\mathrm{t}$ \\
10 & $\mathrm{nt}$ & $\mathrm{nt}$ & $\mathrm{nt}$ & $\mathrm{nt}$ & $\mathrm{nt}$ & $\mathrm{nt}$ & $\mathrm{nt}$ & $\mathrm{nt}$ & $\mathrm{nt}$ & $\mathrm{nt}$ \\
\hline
\end{tabular}

Note: $n t=$ pairs of isolates is not tested, $t=$ pairs of isolates is tested 


\section{RESULTS AND DISCUSSION}

All indigenous rhizobacteria are able to dissolve phosphate, fix nitrogen and produce IAA hormone (Table $2)$. The highest nitrogen production was produced by isolate code $6(0.66 \%)$ and the lowest was produced by isolate code $10(0.22 \%)$. The difference of nitrogen production can be due to grow ability and the nitrogen binding capacity of each isolate. The results of the previous study showed that nitrogen fixation depends on bacterial strains and environmental conditions. Preliminary growth experiments and genome analyses by Op den Camp et al. (2009) indicated that methanotrophic bacteria, Methylacidiphilum strains are able to fix nitrogen. It may also be caused by the activity of the Nitrogenase enzyme in producing ammonium.

The nitrogen fixation process in rhizobacteria is catalyzed by nitrogenase enzyme, this enzyme is very sensitive to high level of oxygen. High concentration of oxygen will inhibit the expression of nifH gene that provides the nitrogenase enzyme. The ability of nitrogen fixation by bacteria can be measured by ammonium accumulation in the growth medium. Besides being used by bacteria, ammonium can also be used by plants., that can provide $30 \%$ or more of the plant's nitrogen demand (Morais et al. 2012).

The highest concentration of phosphate was obtained from isolate code $5(18,927 \mathrm{ppm})$, followed by isolate code $7(18,906 \mathrm{ppm})$, while the lowest concentration was shown by obtained from isolate code $8(8,828 \mathrm{ppm})$. The difference in the solubility of phosphate may be due to the difference in the ability of each isolate to release secondary metabolites.

IAA concentrations in growth medium ranged from 11,270 ppm - 1,524 ppm, where the highest concentration was detected isolate code 5 and the lowest isolate code 10 . The difference IAA concentration might be caused by temperature, $\mathrm{pH}$, strain and time in the growth phase of each isolate. Bacteria start to produce IAA at the beginning of growth and reach its maximum at the beginning of the stationary phase (Patil et al. 2011). While the study by Khamna et al. (2010) reported that maximum production of IAA by Streptomyces sp. was obtained at $30^{\circ} \mathrm{C}$ and $\mathrm{pH} 7.0$

IAA production is also influenced by the supply of Ltryptophan as a precursor in IAA synthesis, because L- tryptophan is an amino acid that acts as a precursor auxin biosynthesis (IAA) in plants and microbes (Patil et al.2011). Karnwal (2009) found that IAA production enhanced with increasing tryptophan concentration. IAA hormones can also be metabolized by several bacteria. IAA producing bacteria are efficient biofertilizer inoculants to promote plant growth. Etesami et al. (2014) reported that seedlings inoculated with IAA produced more shoot biomass (stem plus leaves), root length and colonization than control.

Table 2. Nitrogen production, dissolved phosphate and IAA production by indigenous rhizobacteria from Gowa and Takalar Districts, Sulawesi (Mean \pm S.D)

\begin{tabular}{cccc}
\hline $\begin{array}{c}\text { Isolate } \\
\text { code }\end{array}$ & $\begin{array}{c}\text { Nitrogen } \\
\text { production } \\
(\%)\end{array}$ & $\begin{array}{c}\text { Dissolved } \\
\text { phosphate } \\
\text { concentration } \\
(\mathbf{p p m})\end{array}$ & $\begin{array}{c}\text { IAA hormone } \\
\text { production } \\
(\mathbf{p p m})\end{array}$ \\
\hline 1 & 0.25 & 18.875 & 2.952 \\
2 & 0.40 & 17.573 & 5.587 \\
3 & 0.54 & 16.031 & 6.444 \\
4 & 0.41 & 18.36 & 9.444 \\
5 & 0.46 & 18.927 & 11.270 \\
6 & 0.66 & 15.464 & 6.333 \\
7 & 0.63 & 18.906 & 2.460 \\
8 & 0.37 & 8.828 & 8.302 \\
9 & 0.39 & 12.474 & 7.698 \\
10 & 0.22 & 18.875 & 1.524 \\
\hline
\end{tabular}

Table 3. Colony diameter of R.solani and Relative Inhibitory Level (RIL) of indigenous Rhizobacteria

\begin{tabular}{ccc}
\hline $\begin{array}{c}\text { Isolate } \\
\text { code }\end{array}$ & $\begin{array}{c}\text { Diameter of } \\
\text { colony }(\mathbf{c m})\end{array}$ & $\begin{array}{c}\text { RIL average } \\
(\boldsymbol{\%})\end{array}$ \\
\hline 1 & 8.0 & 0.0 \\
2 & 8.0 & 0.0 \\
3 & 7.3 & 8.8 \\
4 & 8.0 & 0.0 \\
5 & 8.0 & 0.0 \\
6 & 7.0 & 12.0 \\
7 & 6.8 & 15.0 \\
8 & 8.0 & 0.0 \\
9 & 7.3 & 8.75 \\
10 & 5.5 & 31.3 \\
Control & 8.0 & 0.0 \\
\hline
\end{tabular}

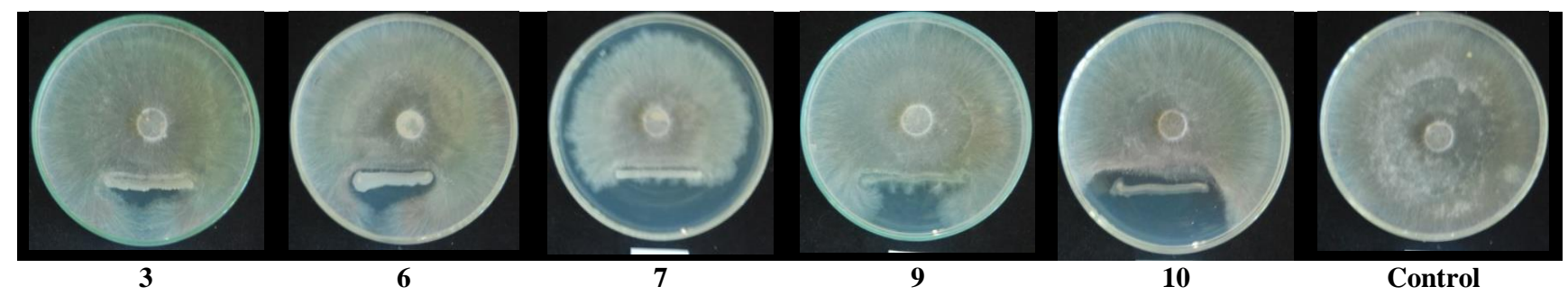

Figure 2. The growth of $R$. solani colony on some Rhizobacteria until 48 hours of incubation 


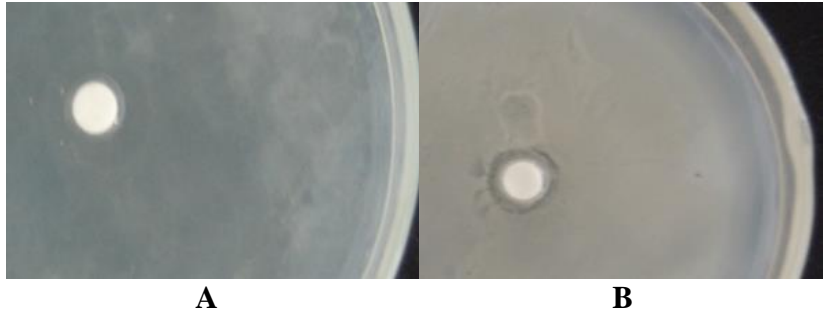

Figure 3. Synergistic analysis of indigenous rhizobacteria from Gowa and Takalar District. (A. not forming clear zone (synergized), B. forming clear zone (not synergized)

Table 4. Matrix for analysis of synergistic pairs of indigenous rhizobacteria which are antagonistic to $R$. solani

\begin{tabular}{cccccc}
\hline Isolate & \multicolumn{5}{c}{ Isolate test } \\
\cline { 2 - 6 } target & $\mathbf{3}$ & $\mathbf{6}$ & $\mathbf{7}$ & $\mathbf{9}$ & $\mathbf{1 0}$ \\
\hline 3 & $\mathrm{nt}$ & $\mathrm{t}$ & $\mathrm{t}$ & $\mathrm{t}$ & $\mathrm{t}$ \\
6 & $\mathrm{nt}$ & $\mathrm{nt}$ & $\mathrm{t}$ & $\mathrm{t}$ & $\mathrm{t}$ \\
7 & $\mathrm{nt}$ & $\mathrm{nt}$ & $\mathrm{nt}$ & $\mathrm{t}$ & $\mathrm{t}$ \\
9 & $\mathrm{nt}$ & $\mathrm{nt}$ & $\mathrm{nt}$ & $\mathrm{nt}$ & $\mathrm{t}$ \\
10 & $\mathrm{nt}$ & $\mathrm{nt}$ & $\mathrm{nt}$ & $\mathrm{nt}$ & $\mathrm{nt}$ \\
\hline
\end{tabular}

Note: $\mathrm{nt}=$ pairs of isolates is not tested, $\mathrm{t}=$ pairs of isolates is tested

Table 5. Results for analysis of synergic pairs of indigenous rhizobacteria

\begin{tabular}{cccccc}
\hline Isolate & \multicolumn{5}{c}{ Isolate test } \\
\cline { 2 - 6 } target & $\mathbf{3}$ & $\mathbf{6}$ & $\mathbf{7}$ & $\mathbf{9}$ & $\mathbf{1 0}$ \\
\hline 3 & $\mathrm{nt}$ & $\mathrm{t}$ & $\mathrm{t}$ & $\mathrm{t}$ & $\mathrm{t}$ \\
6 & $\mathrm{nt}$ & $\mathrm{nt}$ & $\mathrm{t}$ & $\mathrm{t}$ & $\mathrm{t}$ \\
7 & $\mathrm{nt}$ & $\mathrm{nt}$ & $\mathrm{nt}$ & $\mathrm{t}$ & $\mathrm{t}$ \\
9 & $\mathrm{nt}$ & $\mathrm{nt}$ & $\mathrm{nt}$ & $\mathrm{nt}$ & $\mathrm{t}$ \\
10 & $\mathrm{nt}$ & $\mathrm{nt}$ & $\mathrm{nt}$ & $\mathrm{nt}$ & $\mathrm{nt}$ \\
\hline
\end{tabular}

Note: $\mathrm{nt}=$ pairs of isolates is not test, $\mathrm{t}=$ pairs of isolates is tested but not synergized, $\mathrm{T}=$ pairs of isolates is synergized

Based on analysis of biopesticide conducted through antagonistic test, 5 indigenous rhizobacteria were able to inhibit the growth of $R$. solani. It is characterized by the formation of clear zone on test medium until 48 hours of incubation period (Figure 2). The isolates code 3,6,7,9 and 10 were antagonistic to $R$. solani, with varying relative inhibitory levels and isolate code 10 had the best relative inhibitory level (31.3\%) (Table 3). Isolate no. 7 showed a fairly good inhibitory mechanism with a relative inhibitory level of $15.0 \%$.

The potential of each isolate in forming a clear zone highly depends on the adaptability each isolate, including ability to survive and fight against toxic compounds produced by pathogens. The resistance is caused by some microbes produce secondary metabolites that can inhibit the growth of other microbes. Some indigenous rhizobacteria produce $\mathrm{H}_{2} \mathrm{~S}$ compounds that can be toxic to other microbes, such as methanotrophic bacteria. In addition, enzymes produced by microbes can also inhibit the growth of pathogens by colonizing the roots of plants so that plants avoid the pathogen attack. Introduction of Bacillus spp. strains as rhizobacteria showed decrease of disease development time, incidence and severity of Ralstonia wilt diseases (Yanti et al. 2018).

Based on analysis of synergistic of 10 pairs indigenous rhizobacteria tested (Table 4), the result showed that there were 4 isolate pairs that can be synergized (Table 5) which were isolate pairs code 3 and 9, 6 and 7, 6 and 9, 6 and 10. This is characterized by the absence of a clear zone as the inhibition zone (Figure 3). The pair of isolates can be recommended as a bacterial consortium.

Indigenous rhizobacteria are bacteria that have been proved to be able to reduce methane gas emissions, so that they can be used as bioremediation agents. In addition, based on a series of analyzes, several isolates have potential to inhibit $R$. solani pathogens, especially isolate code 10 with a relative inhibitory level of $33.1 \%$ and capable of fixing nitrogen, dissolving phosphate and producing IAA. the isolates have the potential biofertilizer and biopesticides agents.

To maximize potential each bacterium, both as a biofertilizer and biopesticide agents, the consortium should be formed in one formulation. However, based on the ability to inhibit R.solani, so that isolate code 10 and 7 have potential to be developed as biopesticide as well as biofertilizer agents, but cannot be combined in one formulation because there is no synergy or antagonism. The isolate pairs that can be recommended to consortium in one formulation are isolated code 10 and 6 , with the consideration that they can live in synergy. Besides, isolate code 10 has the highest RIL of $31.3 \%$, the soluble phosphate concentration is $18.875 \mathrm{ppm}$, while isolate code 6 produces the highest nitrogen $(0.66 \%)$, hormone production $6,333 \mathrm{ppm}$, so both potential as biofertilizer and biopesticide agents. The pairs of isolates 3 and 9; 6 and 7; and 6 and 9 , also have the potential to form a consortium in one formulation, because they can synergize, but their potential as biopesticide is still low.

In conclusion, all isolates have potential as biological fertilizers because they are capable of fixing nitrogen, dissolving phosphate and producing hormone Indole Acetic Acid. Isolate code 10 can inhibit the growth of Rhizoctonia solani with best of Relative Inhibitory Level (31.3\%), and can live in synergy with isolate code 6 . Isolates code 10 and 6 can be recommended as biofertilizer and biopesticide agents and can be formed as a consortium to biological fertilizers.

\section{ACKNOWLEDGEMENTS}

The authors would like to thank the Director General of the Indonesian Agency for Agricultural Research and Development, the Ministry of Agriculture, for providing funding assistance through the KP4S program in the fiscal year of 2017. Thanks also addressed to the staff and researchers of the Indonesian Cereals Research Institute who has helped carry out this research both in the laboratory and in the greenhouse. 


\section{REFERENCES}

Ashrafuzzaman M, Hossen FA, Ismail MR, Hoque Md.A, Islam MZ, Shahidullah. 2009. Efficiency of Plant Growth Promoting Rhizobacteria (PGPR) for the enhancement of rice growth. Afr J Biotechnol 7: 1247-1252.

Bao Z, Okubo T, Kubota K, Kasahara Y, Tsurumaru H, Anda M, Ikeda S, Minamisawa K. 2014. Metaproteomic identification of diazotrophic methanotrophs and their localization in root tissues of field-grown rice plants. Appl Environ Microbiol 80: 5043-5052.

Guetierrez CK, Matsui GY, Lincoln DE, Lover CR. 2009. Production of the Phytohormone Indole-3Acetic Acid by the estuarine species of the genus Vibrio. Appl Environ Microbiol 75: 2253-2258.

Etesami H, Hossein M, Hossein A. 2014. In planta selection of plant growth promoting endophytic bacteria for rice (Oryza sativa $\mathrm{L}$ ). J Soil Sci Plant Nutr 14: 491-503.

Karnwal A. 2009. Production of Indol acetic acid by fluorescent Pseudomonas in the presence of L. Tryptophan and rice root exudates. Journal of Plant Pathology 91: 61-63.

Khadem AF, Pol A, Jetten MS, Op den Camp HJ. 2010. Nitrogen fixation by the verruco-microbial methanotroph 'Methylacidiphilum fumariolicum' SoIV. Microbiology 156: 1052-1059.

Khamna S, Yokota A, Peberdy JF, Lumyong S. 2010. Indole-3-acetic acid production by Streptomyces sp. isolated from some Thai medicinal plant rhizosphere soils. Eur Asia J BioSci 4: 23-32.
Morais R, Gueseda MD, Reis MS, Urguiaga S, Alves BR, Boddey RM. 2012. Contribution of biological nitrogen fixation to Elephant grass (Pennisetum purpureum Schum). Plant Soil 356: 23-34.

Nonci M, Baharuddin, Burhanuddin R, Firman. 2016. Analysis of potential reduce methane gas emission by Methanotrophs bacteria from rice field in Gowa. Modern Appl Sci 7: 186-190.

Op den Camp HJM, Islam T, Stott MB, Harhangi HR, Hynes A, Schouten S, 2009. Environmental, genomic and taxonomic perspectives on methanotrophic Verrucomicrobia. Environ Microbiol Reports 1: 293306.

Patil NB, Gajbhiye M, Ahiwale S, Gunjal AB, Kapadnis BP. 2011. Optimization of Indole 3-Acetic Acid (IAA) production by Acetobacter diazotrophicus L1 isolated from. sugarcane. J Environ Sci 2: 307-314.

Stella M, Suhaimi M. 2010. Selection of suitable growth medium for freeliving diazotrophs isolated from compost. J Trop Agric and Fd. Sc 38: 211-219.

Yanti Y, Warnita, Reflin, Munsir B. 2018. Indigenous endophyte bacteria ability to control Ralstonia and Fusarium wilt disease on chili pepper. Biodiversitas 19: 1532-1538.

Zhang J, Xue A, Tambong J. 2009. Evaluation of seed and soil treatments with novel Bacillus subtilis strains for control of soybean root rot caused by Fusarium oxysporum and $F$. graminearum. Plant Dis 93: 1317-1323. 